\title{
O CONTRATO DE SUPRIMENTO ENQUANTO MEIO DE FINANCIAMENTO DA SOCIEDADE
}

\author{
Deolinda Aparício Meira
}

\section{SUMÁRIO}

1. Introdução

2. Os suprimentos e a subcapitalização da sociedade

2.1. Noção de subcapitalização

2.2 Meios de combate à subcapitalização

2.3. O linanciamento voluntário pelos sócios (os suprimentos)

2.4. A natureza jurídica dos suprimentos

3. Os elementos do contrato de suprimento

3.1. Os sujcitos

3.2. Carácter de permanência dos créditos cedidos

4. O regime do contrato de suprimento

4.1. Âmbito de aplicação

4.2. Fonte da obrigação

4.3. Objecto da obrigação

4.4. A forma do contrato

4.5. Possibilidade de remuneração

4.6. Regime de restituição

4.7. Sanção do incumprimento

4.8. Tratamento contabilístico

5. Conclusão 


\section{Introdução}

O CSC ocupa-se, nos artigos 243." a $245 .^{\circ}$, do "Contrato de suprimentom'. Neste trabalho propomo-nos fazer um comentário aos referidos preceitos, tendo por referência o contrato de suprimento, enquanto meio de financiamento da sociedade.

Os artigos $243 .^{\circ}$ a $245 . "$, que tratam desta figura, integram-se no CSC, na parte relativa às sociedades por quotas².

Os suprimentos permitem aos sócios satisfazer inúmeros interesses, destacando-se o de fazer face às situações de subcapitalização da sociedade.

Note-se, todavia, que, no nosso sistema, não é necessário, para haver contrato de suprimento, que a sociedade se encontre numa situação de crise. O suprimento existe seja qual for a situação financeira da sociedade, podendo o linanciamento por meio de suprimentos visar, por exemplo, o desenvolvimento ou a expansão da actividade social ${ }^{3}$.

\section{Os suprimentos e a subcapitalização da sociedade}

\section{1. Noção de subcapitalização}

A sociedade deve possuir, desde a sua constituição, um núcleo patrimonial formado por bens com os quais os sócios contribuem, ou seja, a sociedade necessita de um capitalt.

Sucede, porém, que as sociedades se confrontam, frequentemente, com falta de meios de pagamento e de bens suficientes para fazer face

\footnotetext{
' Pertencerão ao Código das Sociedades Comerciais (CSC) todas as disposiçoes legais citadas sem indicação de proveniência.

'Os artigos 243." a 245." do CSC estão inclúdos no Capítulo IV (Contrato de suprimento) do Título IIl (Sociedades por quotas).

"Vor RAUL VENTURA, O contralo de suprimento no Código ders Sociedades Comerciars, Revista O Direito, Ano 121." Janeiro-Março, 1989, pág. 44.

+O capital social constitui um elemento essenciat nas sociedades de capitais, nas quais desempenha un papel fundamental. Lstas sociedades têm, necessariamente, un capital social (art. 9.", n." 1, alinca l) do (SC). Nestas sociedades, os sócios sâo sócios
} 
aos seus compromissos perante os credores em geral, designadamente, os fornecedores, os trabalhadores, o fisco, entre outros, a fim de poderem prosseguir a sua actividade.

Esta frustração da garantia dos credores resulta da existencia de sociedades subcapitalizadas, ou seja, sociedades com um capital desadequado relativamente a objecto socials.

Em muitos casos, esta insuficiência cconómica verifica-se ah initio, na sociedade. É o caso das socicdades que se constituem com o capital minimo legal para operar em sectores de mercado ou de produtos euja comercializaçăo envolve grandes transaç̧òes e quantias. Dizemos que, num caso destes, a socicdade iniciou a sua actividade com um substrato financeiro desadequado à dimensão das responsabilidades que o seu objecto implicava. É a chamada subcapitalização relativa inicial.

Refira-se que esta situação é propiciada pelos montantes mínimos de capital exigidos para as nossas sociedades (5000 euros paras as sociedades por quotas, nos termos do art. 201.", e 50000 euros para as sociedades anónimas, nos termos do art. $276 .{ }^{\circ}, \mathrm{n} . " 3$ )". $\Lambda$ isto acresce o facto de os sócios poderem não realizar todo esse capital no acto de constituição da sociedade, uma vez que podem, mediante estipulação contratual, diferir metade ou $70 \%$ das entradas em dinheiro, consoante se trate de sociedade por quotas ou anónima'. Isto significa que as sociedades podem iniciar a sua actividade com créditos sobre os sócios

unicamente em funçào da stla entrada de capital, sendo também cm funçào desta entrada que se fixam, en principio, os seus direitos sociais. Sobre este assunto ver PAULO DE TARSO DOMINGUES, Do capital social. Noçao. Primeipios e fumçoes, Coimbra Editora, 1998 , págs. 23 e ss.

Sobre este assunto ver PAULO DE TARSO DOMINGULS, Do capital social. Noçcóo. Principios e Funcés, cil., págs. 159 e ss.; RAUL VENTURA, O contrato de suprimento no Código das Sociedudes (omerciass, cit., pags. 17 e ss.; ALEXANDRE MOTA PINTO, Do contrato de Siprimento. O financiamento de socicelade entre capial promio e capital alheio. Almedina, 2002, págs. 97 a ss.; JOÃO AVEIRO PLERERA, $O$ contrato de suprimento, 2." edição, Coimbra Editora, 2001, págs. 19 e ss. "Ver AI.FXANDRE MOTA PINTO, Do contrato de Suprimento. O financiamento da sociedacte entre capital próprio e capital atheio, cil pág. 102 e ss.; JOÃO AVLIRO PEREIRA, O contrato de suprimento cil., pág. 22.

O arl. 202.", 11." 2, estabelece, para as sociedades por quotas, que "Só pode ser dilerida

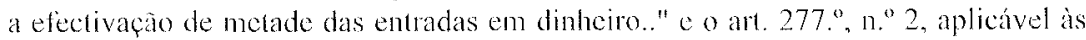


e sem os meios líquidos que thes permitam exercer efectivamente a sua actividade. Esta possibilidade legal de diferimento de realização das entradas é mais grave nas socicdades anónimas, uma vez que a lei permite que os sócios constituam uma sociedade realizando, de imediato, apenas $30 \%$ do valor das entradas. Na prática, isto significa que uma sociedade anónima pode iniciar a sua actividade dispondo, apenas, de meios líquidos fornecidos pelos sócios, no valor de $15000 e^{8}$.

Estamos, então, perante uma subcapitalização congénita, uma ve'z que a sociedade constitui-se $a b$ initio com um capital relativamente diminuto.

A subcapitalização pode resultar, igualmente, de uma perda subsequente de capital, uma vez que a sociedade constitui-se com um capital suficiente, mas há uma descapitalização superveniente. Esta descapitalização surge como o resultado de um excesso de endividamento em comparação com capitais próprios.

A jurisprudência alcmã distingue, a este propósito, entre subcapitalização material e subcapitalização nominal.

A subcapitalização material verifica-se quando a sociedade, dotada de um capital relativamente desproporcionado face ao seu objecto, sc encontra numa situação de carência de fundos e não é financiada, nem com aumento de capital, nem com cmpréstimos, nem sequer com suprimentos dos sócios. A sociedade não tem meios adequados e suficientes para o desenvolvimento da actividade social que se propõe excreer".

sociedades anónimas, estabelece que "Nas entradas em dinheiro só pode ser diferida a realização de $70 \%$ do valor nominal das acções..".

"ALEXANDRE MOTA PINTO, Do contrato de Suprimento. O financiamento da sociedade entre capital próprio e capital alheio, cit., pág. 105, sustenta que, sendo a sociedade anónima uma forma jurídica destinada à grande empresa, deve, por isso. estar disponivel apenas para projectos empresariais que demonstrem, ab initio, uma certa consistência. Neste sentido, o legislador deveria impor a este tipo de sociedades a exigência formulada no art. 202." n." 2 , para as sociedades por quotas, de que as entradas realizadas no momento da realização do contrato perfaçam logo o capital mínimo fixado na lei.

"Ver JOÃO AVEIRO PEREIRA, O contrato de suprimento, cit., pág. 23 e PAULO DE: TARSO DOMINGUES, Do capital social, cit., págs. 167 e ss. 
A subcapitalização nominal verifica-se quando a uma sociedade em situação de carência de fundos são atribuídos meios financeiros necessários ao desenvolvimento da sua actividade, não a título de aumento de capital próprio "1", mas de capital de crédito, ou seja, a título de empréstimo ou de suprimentos".

\subsection{Meios de combate à subcapitalização}

\subsubsection{Princípio da conservação do capital ou da intangibilidade do capital social}

O capital social define-se como uma cifra representativa da soma das entradas dos sócios e desempenha três funções principais: permite a determinação da situação económica da sociedade; permite quantificar os direitos fundamentais dos sócios; c representa uma garantia face a terceiros, designadamente, os credores da sociedade'?

Quanto a esta última função, convém referir que ela se torna particularmente relevante numa sociedade de capitais, uma vez que os credores destas sociedades estão sujeitos a riseos acrescidos. Não esqueçamos que, nas sociedades de capitais, os créditos são pagos apenas à custa do património da sociedade e nunca à custa do património pessoal dos sócios ${ }^{13}$.

O capital social constituirá, desta forma, um mecanismo preventivo de protecção dos credores.

\footnotetext{
16 O capital próprio de uma sociedade define-se como o capital formado pelo seu capital social, pelas suas reservas, pelos lucros transferidos de anos anteriores, pelo lucro do exercício e pelas prestações suplementares dos sócios. Por sua vez, o capital alheio será constituído pelos fundos com que terceiros, estranhos à sociedade, a financiaram. Vejam-se as considerações feitas a propósito desta distinção por ALEXANDRE MOTA PINTO, Do contrato de Suprimento. O financiamento da sociedade entre capital próprio e capital alheio, cit., págs. 21 e ss.

"Ver. JOÃO AVEIRO PEREIRA, O contrato de suprimento, cit., pág. 23.

12 Sobre este aspecto ver PAULO DE TARSO DOMINGUES, Do capital social. Noção, Princípios e Funções, cit., págs. 13 e ss.

1.3 Nestas sociedades, a responsabilidade dos sócios limita-se à realizaçâo das entradas: art. 197." do CSC, para as sociedades por quotas, e art. 271." do CSC, para as sociedades anónimas.
} 
O capital social não é sinónimo de património social (acervo de bens), ainda que, no acto de constituição da sociedade, o capital social coincida com o património social. Quando a sociedade inicia a sua actividade verifica-se uma dissociação entre os dois valores, devendo normalmente o património englobar o capital, na medida em que qualquer sociedade comercial é vocacionada para a obtenção de lucros ${ }^{14}$.

Sempre que o património social se revela escasso para asscgurar a satisfação dos interesses dos credores e a sociedade não consegue obter crédito externo, isto significa que a sociedade está numa situação desfavorável do ponto de vista cconómico e financeiro, prejudicando deste modo os credores.

O legislador tomou algumas cautelas para evitar a proliferação destes casos, cautelas estas que se consubstanciaram no princípio da intangibilidade do capital social.

Este princípio visa "impedir a distribuição aos sócios de bens ou quantias necessárias para manter intacta a soma do capital e das reservas obrigatórias".

Segundo Miguel Pupo Correia ${ }^{15}$, este princípio comporta três acepções:

- insusceptibilidade de distribuição pelos sócios de quantias necessárias para manter intacto um fundo patrimonial lícquido equivalente, pelo menos, ao capital ${ }^{16}$;

- exigência de que, por virtude de perdas, o património líquido da sociedade não deixe de manter certa proporção mínima com o capital social ${ }^{n}$;

- imodificabilidade, salvo em termos controlados, do capital social, para mais ou para menos ${ }^{18}$.

\footnotetext{
1. O património social é un fundo real de bens e direitos, efectivo, concreto e continuamente variável na sua composição e montante, enquanto que o capital social é una cifra constante. Ver sobre esta distinção PAULO DE TARSO DOMINGUES, Do capital social. Noçăo, Principios e Funçöes, cit., págs. 41 e ss.

15 Ver MIGUEL PUPO CORREIA, Dircito Comercial, 8. "edição, Ediforum, Lisboa, 2003 , págs. 548 e ss.

"Esta acepção resulta dos artigos 29." e $31 .{ }^{\circ}$ a $34 .^{\circ}$ do CSC.

${ }^{17}$ Esta segunda acepção resulta do art. $35^{\circ}$ do CSC

"Esta terceira acepção está tratada nos artigos $87.0^{\circ}$ a 96.", $201 .^{\circ}$, in fine, $266.0^{\circ}$ c $456 . "$ a 462." todos do CSC.
} 
Estamos a falar de um princípio que consagra que o capital social real" não poderá ser diminuído em resultado da atribuição de bens aos socios. Assim, ao inscrever-se o capital social no lado dircito do balanço, ele assume-se como uma cifra de retenção, na medida em que impede que sejam distribuidos aos sócios bens do património, se o valor líquido deste não superar o valor daquele ${ }^{21}$.

\subsubsection{Capital mínimo legal adequado ao objecto social}

Como já foi referido, a subcapitalização das sociedades implica riscos para a esfera dos credores, defendendo a doutrina a consagraçâo de um dever dos sócios de dotar a sociedade com um capital adequado ao objecto social, a fim de evitar aqueles riscos. Este dever consubstanciar-se-ia no chamado principio da adequação do capital ao objeclo da sociedade". Segundo Raul Venturs, o legislador pressupõe que a fixação do capital não seja arbitrária, mas mantenha uma relação com o objecto social ${ }^{2}$.

Daqui resulta que a consagração deste princípio justificar-se-ia uma vez que as sociedades têm necessidades de capital distintas, de acordo com o seu volume de negócios e os riscos económicos envolvidos no tipo de actividade que exereen.

Neste sentido, será defensável, na esteira da posição de PAulo dE TARSo Domingues, que o notário, no exercício do seu controlo de

"Por capital social real entende-se aquela fracçào ideal do activo que se destina à cobcrtura da cifra do capital social nominal. O capital social nominal setá a cifra constante do pacto, que năo se perde, e nào necessita, por isso, de quaisquer cautetas quanto a sua conservação. Sobre estas noçoes, vejam-se as consideraçoes de PAULO

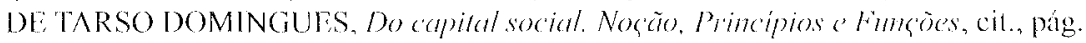
104.

"Ver PAULO DE IARSO DOMINGULS, Garamias da Consistência do Parimónio Social, in Problemas do Direiro das Sociedodes. Almedina, 2003, págs. 520 e ss.

"Princípio que não tem consagraçõo legal. Todavia, PAULO DE TARSO

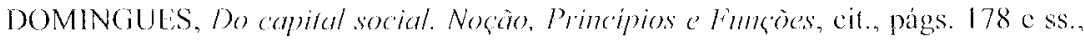
defende que este princípio seria inferivel do próprio regime do capital social. Segundo este autor, o capital social não desempenhará satisfatorianente uma função de garantia dos terceitos credores se não se conseguit a adequação do capital ao objecto social.

"Ver RAUL, VENTURA, O conrrato de smprimento no Código das Sociedades Comerciasis, cit., pág. 20. 
legalidade, possa recusar a celebração de escritura pública de uma sociedade que fosse constituída com um capital irrisório, tornando manifestamente impossível a prossecução do objecto social ${ }^{23}$.

Este princípio da adequação entre o capital c o objecto social levanta algumas questões que importa abordar. Este princípio implicaria desde logo:

- a defesa da elevação do capital mínimo legal previsto para as sociedades por quotas e anónimas; tal como já foi referido, os montantes actualmente previstos revelam-se exíguos para a maioria das sociedades a que se destinam, podendo uma sociedade entrar, desde logo, numa capitalização insuficiente para a generalidade dos ramos de negócio ou de serviços a que pretenda dedicar-se;

- a adopção, na nossa ordem jurídica, de medidas legislativas que elevem o montante do capital mínimo geral a um nível mais ajustado à realidade sócio-cconómica actual, nomeadamente, em relação às economias da União Europeia ${ }^{24}$,

- para evitar o rápido desgaste do valor fixado para o capital, deve o mesmo ser indexado ao cvoluir da inflação ${ }^{25}$;

- exige-se uma maior adequação do capital social ao volume e à importância dos negócios da respectiva sociedade; aliás, isto já

\footnotetext{
"Numa situação deste tipo, estaríamos perante uma impossibilidade do objecto, que teria como consequência a nulidade do contrato de sociedade (art. 280." do C. Civil). Ver PAULO DE TARSO DOMINGUES, Do capital social. Noção. Principios e Funcớes, cit., pág. 179. Como voz discordante, AlEXANDRE MOTA PINTO, Do contrato de Suprimento. O financiamento da sociedade entre capital próprio e capital alheio, cit., págs. 91 e ss., o qual defende que ao notário cabem apenas poderes de controlo da legalidade do contrato de sociedade, não dispondo de qualquer poder de controlo material sobre a viabilidade da empresa, em função da relação entre o seu capital e o objecto social. Este juízo estaria reservado aos sócios.

${ }_{24}$ Ver JOÄO AVEIRO PEREIRA, O contrato de suprimento, cit, págs. 32 e ss.

"Os limites mínimos de capilal sofrem uma erosão provocada pela inflação. Podemos apontar como exemplo claro desta erosão o das sociedades por quotas, cujo capital mínimo foi, entre 1901 e 1961 , de $5000 \$ 00$, tendo o Decreto-Lei n.. 43843 , de 5 de Agosto de 1961, alterado o art. 4." da Lei das Sociedades por Quotas de 1901, no sentido de elevar o capital mínimo para $50000 \$ 00$. Este montante manteve-se até à entrada em vigor do novo Código das Sociedades Comerciais. Este diploma veio consagrar como capital mínimo para as sociedades por quotas Esc. $400000 \$ 00$, passando a partir de 1 de Janeiro de 2002 para $€ 5000$.
} 
acontece com as sociedades que operam na área financeira; trata-se, portanto, de adequar o capital ao objecto da sociedade.

\subsubsection{Emissão de obrigações que não excedam a importância do capital realizado e existente (art. $3490^{\circ}$ do CSC)}

Nos tcrmos do art. 348.", n. ${ }^{\circ} 1$ as obrigações são "títulos negociávcis que, numa mesma emissão, conferem direitos de crédito iguais, para o mesmo valor nominal».

As obrigações, sendo títulos de crédito, podem ter como relação subjacente $\mathrm{e}^{26} \mathrm{um}$ contrato de mútuo ${ }^{27}$.

Como assinala PeDro PAIS de VAsconcelos o empréstimo obrigacionista é «um tipo de cooperação entre capital e empresa no âmbito do comércio $)^{28}$, constituindo, portanto, a emissão de obrigações um outro meio de combate à subcapitalização"s.

\subsubsection{Desconsideração da personalidade colectiva}

A desconsideração da personalidade colcetiva justificar-se-ia nos casos mais graves de subcapitalização.

Estamos a falar de um método de «derrogação ou não observância da autonomia jurídico-subjectiva e/ou patrimonial da pessoa colectiva

\footnotetext{
"A relação subjacente é a causa.

"As obrigaçòes podem ter como relação subjacente um mútuo puro, o que acontece quando as obrigaçôes dão simplesmente direito ao pagamento de um juro e da amortização. As obrigações podem também ter como relação subjacente mútuos parciários, o que ocorre quando dâo direito a um crédito cujo montante é influenciado pelo resultado da sociedade emitente [art. 360.', alineas a) e b)]. Ver PLDRO PAIS DE VASCONCELOS, As obrigaçóes no financiamento da empresa, in Problemas do Dircito das Sociedades, Almedina, 2003, págs. 321 e ss.

${ }^{2 *}$ PEDRO PAIS DE VASCONCELOS, As ohrigaçós no financiamento da empresa, cil., pág. 323.

2) ALEXANIDRE MOTA PINTO, Do contrato de Suprimento. O financiamento da sociedade entre capital próprio e capilal alheio, cit., pág. 45, refere que uma forma típica de as sociedade anónimas obterem capitais alheios, a longo prazo, é a emissão de obrigações. As sociedades por quotas podem, igualmente, emitir obrigações, ainda que na prática esta faculdade não seja muito utilizada por este tipo de sociedades, visto a emissão de obrigações constiluir uma forma típica de financiamento da grande cmpresa.
} 
en face dos seus membrosy i".

Quando os sócios levam a cabo actos de endividamento excessivo poderá desconsiderar-se a personalidade colectiva, responsabilizando também os sócios por acquela situação. Os credores dirigir-se-ão então aos sócios para obterem a satisfação dos seus créditos. A subcapitalização seria remediada pelo recurso do património individual dos sócios, «despedaçando o véu ou a cortina da personalidade colectiva, para atingir o verdadeiro e real substrato, que são os sócios»".

\subsection{O financiamento voluntário pelos sócios (suprimentos)}

Una das formas de compensar as situações de subcapitalização nominal das socicdades, sobretudo no que se refère às socicdades por quotas, será o recurso aos suprimentos dos sócios?3.

Este tipo negocial constitui um meio contratual de financiamento da sociedade pelos sócios. ( art. 243.", n." I define-o como «o contrato pelo qual o sócio empresta à sociedade dinheiro ou outra coisa fungivel, ficando aquela obrigada a restituir outro tanto do mesmo género e qualidade, ou pelo qual o sócio convenciona com a sociedade o diferimento do vencimento de créditos seus, desde que, em qualquer dos casos, o crédito ficue tendo carácler de permanência».

Assim, os suprimentos são cmpréstimos dos sócios à sociedade, para acorrer a necessidades momentâneas de liquidez e possibilitar o restabelecimento do equilíbrio financeiro da sociedade, podendo ser feitos livremente ou em execução de uma obrigação de prestação acessória.

$O$ contrato de suprimento destaca-se pelo facto de poder ter por objecto dinheiro ou outra coisa lungível, não se limitar ao mero empréstimo de fundos, podendo abranger igualmente a dilação do prazo de pagamento de um crédito do sócio sobre a sociedade.

\footnotetext{
"OUTINHO DH ABRLU, Da empresarialidade. Almedina, 1999, pág. 205.

"RAUL VENTURA, O contato de suprimento no Código das Sociedades Comerciats, cil., pág. 18.

A subcapitalizaçăo deve-se, provavelmente, aos próprios sócios, uma vez que foram cles que, inicialmente, não dotaram a sociedade de meios suficientes.
} 
Um dos elementos essenciais para a caracterização do contrato de suprimento consiste, nos termos do art. 243. , na duração da disponibilidade dos fundos postos à disposição da sociedade pelo sócio. Assim, para que um crédito seja considerado crédito de suprimento, o prazo de reembolso não deve ser inferior a um ano.

Na actual prática comercial, os suprimentos apresentam a grande vantagem de evitarem o recurso ao crédito externo, em não implicarem as formalidades legais, a morosidade e os condicionamentos do aumento de capital, e ainda a forte proteç̧ão dos credores sociais inerente ao regime juridico deste lipo negocial.

No contrato de suprimento, o sócio passa a revestir duas qualidades: a de sócio e a de credor da sociedade ${ }^{33}$. Os sócios, para além de contribuírem com bens e serviços para a formação do capital, habilitam a sociedade com dinheiro ou outros bens, a restituir mais tarde, destinados a lazer face alos seus compromissos financeiros.

Ao contrário das entradas para o capital social, os suprimentos podem ser restituídos aos sócios em qualquer altura e podem vencer juros.

Ao recorrerem aos suprimentos, os sócios, $\mathrm{cm}$ vez de aumentarem o capital, estão a provocar uma distorção no funcionamento da sociedade, mantendo-a artilicialmente a viver acima dos seus próprios meios. O contrato de suprimento provoca, por isso, uma situação fictícia quanto à capacidade financeira da sociedade.

Ilá situações em que, aos sócios, não interessa recorrer ao aumento do capital social, dadas as demoras e os condicionamentos do aumento de capital. Nestes casos, os contratos de suprimentos surgem como uma alternativa ao aumento do capital social.

Quanto à forte protecção dos credores sociais, ela resulta sobretudo do facto de, em caso de falência, os seus créditos nào sofrerem a concorrência dos credores de suprimentos, o que será objecto de análise desenvolvida, mais adiante.

B. RAUL, VENTURA, O contrato de suprimento no (ódigo das Sociedades Comercias, cit., pág. 23 , alerta para o facto de que ao sócio nâo convém qualquer ligação entre as duas qualidades. (itando um autor alemào, RAUL VENTURA afirma que "o alvo é ser sócio nos direitos, mas estranho nos deveres". 


\subsection{A natureza jurídica dos suprimentos}

É tempo de analisarmos a natureza jurídica dos suprimentos.

Antes do CSC, o contrato de suprimento não tinha um regime específico, sendo tido como um contrato de mútuo (o suprimento como um verdadeiro contrato de empréstimo do sócio à sociedade) e, portanto, ficariam sujcitos à disciplina dos artigos 394." a 396." do C. Comercial, desde que os dinheiros eedidos fossem destinados à prática de actos de comércio.

Esta equiparação do suprimento à figura do mútuo ou empréstimo começou a revelar-se insuficiente, pelas seguintes razões:

- no mútuo, o credor pode exigir o seu crédito logo que se ache vencido (art. 777." do C. Civil); ora, seria prejudicial aos interesses da sociedade que um sócio credor de suprimentos pudesse exigir, de um momento para o outro, a restituição imediata das importâncias entregues à sociedade, deixando-a, eventualmente, impossibilitada de prosseguir a sua actividade por falta de liquide $z^{34}$,

- a outra razão é que o credor de suprimentos não pode ser recmbolsado da mesma forma que os outros credores; a aplicação das regras do mútuo aos suprimentos levaria também a que o sócio credor, em caso de falência ou de liquidação, fosse considerado como qualquer outro credor; ora, isto não é aceitáve!, uma vez que o sócio credor por suprimentos dispõe de uma relaçăo privilegiada com a sociedade, está por dentro da organização e, muitas vezes, tem até responsabilidade nessa situação falimentar, nomeadamente, enquanto gerente ou administrador;

- o suprimento pode não consistir numa entrega de dinheiro ou de outra coisa fungível; o suprimento pode decorrer de um não levantamento de lucros distribuídos ou da não cobrança de qualquer outro crédito do sócio ${ }^{35}$.

Face ao exposto, podemos afirmar que o suprimento é uma figura

\footnotetext{
3. O credor de suprimentos poderia exigir da sociedade o reembolso a todo o momento, o que se revelaria prejudicial.

${ }^{35}$ Sobre estes aspectos ver JOÃO AVERRO PEREIRA, O contrato de suprimento, cil., págs. 51 e ss.
} 
contratual autónoma, sendo o Código das Sociedades Comercial o primeiro diploma, em direito português, a regulamentar esta matéria, mas apenas em sede de sociedade por quotas.

Os elementos e o regime legal do contrato de suprimento encontram-se nos artigos 243." a 245.", que passamos a analisar.

\section{Os elementos do contrato de suprimento}

\subsection{Os Sujeitos}

O contrato de suprimento tem como partes uma sociedade e um sócio desta.

a) A sociedade

No contrato de suprimento, a relação negocial estabelece-se entre uma sociedade e os sócios, estando a sociedade do lado passivo. Trata-se de uma pessoa colectiva, com personalidade e capacidades jurídicas (artigos 157. , 158..$^{\circ}$ e $1600^{\circ}$ ), formando-se a sua vontade no seio dos respectivos órgãos e expressando-se através de pessoas físicas que em cada momento a representam (artigos 162." a 164.').

Refira-se que o contrato de suprimento não pode ocorrer depois da sociedade ter sido dissolvida.

b) O sócio

O sócio é aquele que figura como tal no contrato de sociedade e aquele que, posteriormente à constituição da sociedade, adquiriu essa qualidade mediante negócio inter vivos ou por sucessăo mortis causa.

Todavia, a propósito de outros eventuais sujeitos interessados nos suprimentos, poderão surgir dúvidas quanto à natureza jurídica da sua posição face à sociedade: o conceito de sócio expresso na lei, corresponde apenas ao titular da quota ou abrangerá outros sujeitos com direitos sobre a mesma participação no capital social, tais como o usufrutuário ou o credor pignoratício? 
b) 1. () usutrutuário

O empréstimo léto à sociedade pelo usufrutuário da quola pode ser um suprimento ${ }^{3,2}$ ?

Apesar de não haver consenso doutrinal, defendemos que o usufrutuário deve ser considerado sócio para efeitos do contrato de suprimento, sendo esta a solução que está mais de acordo com os poderes que o usufrutuário de participações sociais tem entre nós". Esta qualificaçăo deve ser generalizada a todos os casos de contrato de suprimento, com base em empréstimos ou diferimento de créditos do usufrutuário, uma vez que este se aproveita dos resultados da actividade social e pode participar no aumento de capital que o suprimento vem substituir (art. 269.") ${ }^{3.5}$.

b) 2. O credor pignoratício

O credor pignoratício (o credor cujo crédito beneficia da garantia de um penhor de participações sociais) adquire o direito de salisfazer o seu crédito à custa das participações sociais empenhadas (art. 666.", n. ${ }^{\circ}$, do C. Civil).

$O$ penhor de participações sociais só pode ser constituído em obediêneia à forma e dentro das condições estabelecidas para a transmissão inter vivos de participações, de acordo com o disposto no art. $230 \%$, n." 3.

Embora não sendo sócio nominalmente, o credor pignoratício comporta-se como um verdadeiro titular da participação social, no fundo como um sócio, dado o seu interesse pessoal relativamente à vida da sociedade e à respectiva participação no capital. Assim, nos

\footnotetext{
3r O usulfuto consiste, como se sabe, no direito de gozar, temporária e plenamente, uma coisa ou dircito alheio (art. 1439.0 do ('. Civil).

"O usufrutuário de participaçoes sociais tem um beneficio com a actividade social. Nos termos do art. 1467.", n." 1, al. b), do (" Civil, tem poderes de voto que the permitem ter uma posição activa ha sociedade, ficando em posição privilegiada face aos restantes credores. Ver ALEXANDRE MOTA PINTO, Do contrato de Suprimento. () financiamento da sociedade entre capital próprio e capital allieio, cit, pag. 274.

"Vor JO ̃O AV EIRO PEREIRA, O contrato de suprimento, cit., págs. 64 e ss.
} 
termos do art 23.", n." 4, o credor pignoratício pode acordar com o sócio o exercício de direitos sociais, tais como o direito aos lucros, o direito de voto e o dircito à informaçào, o que the permitirá desempenhar um papel mais activo na sociedade.

Daqui resulta que nada impede que o credor pignoraticio da quota seja também credor de suprimentos, fazendo-o com a finalidade de assegurar a existencia e a conservação da quota ou das acções empenhadas ${ }^{31}$.

c) Créditos de terceiros sujeitos ao regine de suprimentos

A sujeição de um crédito ao regime dos suprimentos está dependente, em primeiro lugar, de, no momento da celebração do respectivo negócio, os sujeitos terem as qualidades de sócio c de sociedade, respectivamente.

No entanto, os créditos são livremente transmissíveis, podendo acontecer que estranhos venham a entrar na sua titularidade ou que um sócio adquira créditos de terceiros sobre a sociedade.

Se un sócio adquire créditos de lerceiros sobre a sociedade e o crédito tem carácter de permanência, então ele passa, a partir da sua aquisição pelo sócio, a ser juridicamente encarado como crédito de suprimentos (art. 243.", n. $\left.{ }^{\circ} 5\right)$.

O mesmo acontece quando um terceiro concede um empréstimo à sociedade com a garantia de um sócio. Se o sócio vier a satisfazer o crédito em substituição do terceiro, o seu direito de regresso sobre a sociedade será tratado como suprimento, desde que tenha carácler de permanência.

Se um sócio credor de suprimentos deixar de ser sócio, esses seus créditos continuam sujeitos ao regime de suprimentos.

E se um sócio transmitir o suprimento a um terceiro que não é nem virá a ser sócio?

Esses créditos continuam abrangidos pelo regime de suprimentos, apesar de o seu novo titular não ser sócio. O art. 245." fala em "credores de suprimentos". Estes podem não ser apenas os sócios, dada

"Ver JOÄO AVEIRO PEREIRA, O comralo de suprimento, cit., págs. 69 e ss. 
a livre transmissão dos créditos e o interesse da sociedade em manter na sua disponibilidade os correspondentes valores ${ }^{41}$.

d) Transmissão da quota: implica ou não a transmissão do suprimento?

A transmissão da quota, por morte ou entre vivos, não tem de ser necessariamente acompanhada da transmissão dos créditos de suprimentos de que o sócio cedente cra titular. O crédito de suprimentos é cindível da participação social, podendo transmitir-se o crédito sem transmitir a quota ou as acções, e vice-versa ${ }^{41}$.

Daqui resulta que pessoas diversas podem suceder hereditariamente na quota e no crédito de suprimentos. É pela interpretação dos testamentos (art. $2187 .^{\circ}$ do C. Civil) e dos contratos de cessão (art. 236. a 239." do CSC) que se terá de determinar se são ou não transmitidos simultaneamente a quota e o crédito de suprimentos.

Quanto à transmissão entre vivos, a quota e os suprimentos podem ser cedidos a pessoas diferentes, sendo também lícito ao cedente manter o crédito de suprimentos e ceder só a quota.

A transmissão da quota não implica a transmissão dos suprimentos a ela associados. No silêncio do contrato de transmissão da quota, entende-se que não houve transmissão de suprimentos.

Em caso de venda da empresa societária, pergunta-se se esta implicará também, automaticamente, a cedência dos créditos de suprimentos juntamente com todos os outros direitos dos sócios afectos ao acervo patrimonial?

Tudo depende da vontade negocial expressa ou tácita das partes, podendo acontecer que as partes, embora transaccionando a empresa, pretendam manter a autonomia dos créditos de suprimentos, ficando os cedentes como seus titulares, embora deixem de ser sócios ${ }^{42}$.

\footnotetext{
*6 Ver JOÃO AVEIRO PEREIRA, O contrato de suprimento, cit, págs. 70 a 73.

"Ver ALEXANDRE. MOTA PINTO, Do contrato de Suprimento. O financiamento da sociedade entre capital próprio e capital alheio, cit., pág. 286.

4. Ver JOÃO AVEIRO PEREYRA, O contrato de suprimento, cit., págs. 73 e ss.
} 


\subsection{Carácter de permanência dos créditos cedidos}

a) O carácter de permanência como elemento objectivo de caracterização do suprimento

No contrato de suprimento podemos distinguir:

- clementos subjectivos (reportam-se directamente à intenção dos sócios) e

- elementos objectivos (desligados do aspecto psicológico que move os sócios ao efectuarem as respectivas entregas à sociedade).

O carácter de permanĉncia dos suprimentos é um elemento objectivo. Em que consiste?

O contrato de suprimento típico concretiza-se em duas modalidades distintas:

- o empréstimo à sociedade de dinheiro ou outra coisa fungível $\mathrm{c}$

- a convenção de diferimento do vencimento de créditos (art. 243. ${ }^{\circ}, \mathrm{n} .{ }^{\circ} 1$ ).

Em qualquer das modalidades, o legislador considerou necessário assegurar à relação contratual uma certa cstabilidade. Fê-lo fixando um limite temporal mínimo, superior a um ano, para a sociedade dispor do objecto do suprimento, antes de o restituir.

Mas se não tiver sido estipulado qualquer prazo, ainda assim pode existir suprimento, desde que o sócio credor não utilize a faculdade de pedir o seu reembolso, pelo menos durante um ano, contado da constituição do crédito (art. 243.", n." s 1, 2 e 3).

A permanência indica que os bens não foram postos à disposição da sociedade de uma forma transitória, tendo sido afectos a fins semelhantes aos do capital ${ }^{43}$.

\footnotetext{
${ }^{43}$ O suprimento corresponde a um crédito a longo prazo. Neste sentido, RAUL VENTURA, O contrato de suprimento no Código das Socicdades Comerciais, cit., pág. 44, a lirma que "(...) permanência não quer dizer etemização, mas opõe-se à transitoriedade, e, portanto, exprime uma função: esses bens são postos à disposição da sociedade em condições que permitem a esta utilizá-los para a generalidade dos fins sociais, como bens que podem ser afectos a esses fins, à semelhança do capital".
} 
b) Presunções de permanência de créditos

A lei estabelece presunções de permanência dos créditos. Assim, 0 art. 243.", n. ${ }^{\circ}$, estabelece que "constitui índice do carácter de permanência a estipulação de um prazo de reembolso superior a um ano, quer tal estipulação seja contemporânea da constituição do crédito, quer scja posterior a esta. No caso de diferimento do vencimento de um crédito, computa-se nesse prazo o tempo decorrido desde a constituiçăo do erédito até ao negócio de diferimento"t+1.

$O$ índice consiste na "não utilização da faculdade de exigir o reembolso devido pela socicdade durante um ano"'s.

Nalgumas situações permite-se que os sócios afastem estas presunçōes ${ }^{\text {th }}$, subtraindo aquelas prestações ao regime desłavorável dos suprimentos ${ }^{+\prime}$.

c) A prova do carácter de permanêneia

En relaçăo ao tempo de disponibilidade pela socicdade de determinado crédito concedido pelo sócio, para efeitos de o sujeitar ao regime dos suprimentos, podem verificar-se três situações concretas:

1) fixação contratual de prazo de reembolso superior a um ano, inicial ou posteriormente acordado;

2) estipulação de prazo de reembolso, igual ou inferior a um ano;

3) não utilização, durante um ano, da faculdade de exigir o reembolso à sociedade.

Em qualquer dos casos, os credores sociais podem provar o carácter de permanência dos créditos:

\footnotetext{
${ }^{4}$ Como exemplo podemos apontar o não levantamento dos luctos distribuidos ao sócio por período igual ou superior a um ano.

1. RAUL VLNTURA, O contrato de suprimento no código das Sociedades Comeriais, cit., pág. 47.

*o Os sócios poderão lazê-lo provando, por exemplo, que o crédito em causa não tinha o carácter de permanencia que se presume e por isso não é um crédito de suprimentos ${ }^{17}$ O sócio que tem a qualidade de fornecedor da sociedade terá vantagens em ilidir essas presunções.
} 
- provando que, apesar do reembolso efectuado antes de decorrido um ano, o crédito do sócio tinha o carácter de permanência, ou

- provando que, apesar de não funcionar o indice legal de permanência, o crédito tinha tal carácterer.

Alexandre Mota Pinto aponta um critério objectivo que permite aos credores sociais provar o carácter de permanência dos créditos: os credores sociais poderão provar que as eondições financeiras da sociedade, no momento do empréstimo ou do diferimento, aumentando consideravelmente os seus riscos, impediam a obtenção de crédito de terceiros em condições normais de mercadot".

Assim, um terceiro não cstaria disposto a financiar a socicdade, uma $v e z$ que esta não dispunha de capital próprio necessário à segurança dos seus créditos. Face ao exposto, será de concluir que os empréstimos realizados pelos sócios destinavam-se a suprir essas insuficiências de capital.

d) O alastamento da presunção de permanência

O art. 243.", n. 4 , ao conceder aos sócios a faculdade de ilidirem a presunção de permanência estabelecida nos seus n. ${ }^{\circ}$ s 2 e 3, aponta o que os interessados têm de demonstrar para afastarem essa presunção e verem os seus créditos livres das limilações próprias dos suprimentos.

Todavia, para o efeito inverso, a favor dos credores externos da sociedade, a lei não indica qualquer modo de provar o carácter de permanência.

Perguntar-se-á então, como provar o carácter de permanência?

Esta prova terá de incidir sobre elementos objectivos e subjectivos.

Deverão ser ponderadas não só as circunstâncias ligadas às vicissitudes do crédito em causa e à situação financeira da sociedade,

\footnotetext{
1* Ver RAUL VENTURA, O contrato de suprimento no código das Sociededes Comerciais, cit., págs. 49 ess.

19 Ver ALFXANDRE MOTA PINTO, Do contralo de Suprimento. Ofinameiamento da sociedade sntre capital próprio e capital alheio, cit., pág. 326.
} 
nomeadamente a afectação do crédito ao objecto social c eventual subcapitalização da empresa, mas támbém a intenção dos sócios que abonaram a sociedade, no momento em que constituíram esse crédito ${ }^{50}$.

\section{Regime do contrato de suprimento}

\section{1. Âmbito de aplicação}

A lei regula os suprimentos apenas a propósito das sociedades por quolas (art. 243. ${ }^{\circ} \mathrm{e} \mathrm{ss}$.).

Todavia, discute-se a questão de saber se o contrato de suprimento pode ou não ser convencionado $\mathrm{em}$ sociedades de outros tipos.

Grande parte da doutrina defende a aplicação, por via analógica, dá disciplina do contrato de suprimento às sociedades anónimas".

Seguimos, no essencial, a posição de Raul Ventura, o qual admite, quanto às sociedades anónimas, a aplicação analógica do contrato de suprimento, quando o accionista-credor seja titular de acções com fins verdadeiramente societários c não titular de acções como simples meio de colocação de capitais ${ }^{52}$. Segundo o referido autor, para efeitos de tal aplicação analógica às sociedades anónimas,

\footnotetext{
sil O sócio pode provar, através de circunstâncias objectivas, que não financiou a sociedade enquanto sócio, mas apenas como o faria qualquer terceiro. ALEXANDRE MOTA PINTO, Do contrato de Suprimento. O financiamento da sociedade entre capital próprio e capital alhoio, cit., pág. 328, defende que, nesta matéria, dever-se-á ter em conta as circunstâncias económico-financeitas da sociedade e as condições contratuais, podendo concluir-se da avaliação das mosmas que aquele empréstimo ou diferimento de crédito poderia ter sido efectuado por um qualquer terceiro, estranho à sociedade.

"Neste sentido, ver RAUL VENTURA, O contrato de suprimento no Código das Socicdades Comerciais, cit., págs. 25 e ss.; PINTO FURTADO, Curso de Direilo das Sociedades, 4:" Edição, Coimbra, Almedina, 2001, pág. 225; PAULO DE TARSO DOMingues, Do capital social. Noção, Princípios e Funcốes, cit., págs. 165 e ss.; JOÃO AVEIRO PEREIRA, O contrato de suprimento, cit., págs. 123 e ss., defende igualmente a aplicabilidade do regime do contrato de suprimento às socicdades anónimas, mas a base dessa aplicação será a interpretação extensiva e não a aplicação analógica.

- Ver RAUL VENTURA, O contrato de suprimento no Código das Sociedades Comerciars, eit., págs. 25 e ss.
} 
o nível mínimo de participação que exprime tal titularidade com fins verdadeiramente societários é o de 10\% do capital social, percentagem esta utilizada pelos artigos $392 .^{\circ} \mathrm{e} 418 .^{\circ}, \mathrm{n} .^{\circ} 1^{53}$. Quanto às sociedades em nome colectivo, deverá rejcitar-se a aplicação do regime dos suprimentos. A proteç̧ão dos credores sociais não se justificaria neste tipo de sociedades, atendendo à responsabilidade ilimitada dos sócios que a caracteriza ${ }^{\text {s. }}$.

\subsection{Fonte da obrigação}

A obrigação de efectuar suprimentos é, em princípio, estranha ao contrato de sociedade, sendo a sua fonte um contrato entre o sócio e a sociedade, que em princípio não depende sequer da deliberação dos sócios (art. 244. ${ }^{\circ}$, n." 3 ).

Todavia, o art. 244. ${ }^{\circ}$, nos seus n. ${ }^{\circ}$ s 1 e 2 , prevê dois instrumentos de constituição da obrigação de efectuar suprimentos: o contrato social e a deliberação dos sócios.

Nas hipóteses em que o contrato de sociedade estabelece a obrigação de efectuar suprimentos, os mesmos reconduzem-se a prestações acessórias (art. 244. ${ }^{\circ}, 10^{\circ}$ 1), aplicando-se o disposto no art. 209. ${ }^{\circ 5}$.

5. O art 392." do CSC utiliza, por duas vezes, a percentagem de $10 \%$ para regras especiais de eleições de administradores. Por sua vez, o art. 418.", n." I, usa a mesma percentagem para o requerimento de nomeação judicial de membro do conselho tiscal. Segundo RAUL VENTURA, O contrato de suprimento no Código das Sociedades Comercicis, cit. pág. 26, estaremos perante duas hipóteses $\mathrm{cm}$ que o interesse societário do accionista é manifesto. Assim, a percentagem de 10\% exprimirá o interesse societário do accionista, para o efeito de contratos de suprimentos.

54 Nas socicdades em nome coleclivo, os sócios respondem pela realização das entradas face à sociedade e pelas dividas da sociedade face aos credores sociais. Esta responsabilidade pelas dívidas da sociedade é solidária entre os sócios, e subsidiária em relação à sociedade. Esta responsabilidade do património pessoal dos sócios pelas dividas sociais exclui a necessidade de tutela dos credores que o regime dos suprimentos traduz. Ver neste sentido, RAUL VENTURA, O contrato de suprimento no Código das Sociedades Comerciais, cit, pág. 27.

5O regime das obrigaçöes de prestaçöes acessórias está previsto nos artigos $209 . " \mathrm{e}$ $287 .^{\circ}$ do CSC. 
Assim, por força desta remissão, aplicar-se-ão à obrigação cstatutária de celebração de contratos de suprimentos os requisitos mencionados no art. 209."

A cláusula contratual deverá, desde logo, estabelecer um limite máximo para o montante de suprimentos que os sócios ficam obrigados a realizar ${ }^{-5}$, o objecto da obrigação de suprimentos, especificando se os sócios ficam obrigados a entregar à sociedade dinheiro ou outra coisa fungível, a modalidade do contrato de suprimento e o carácter oncroso ou gratuito dos suprimentos.

No que respeita ao montante de suprimentos que cada um dos sócios fica obrigado a realizar, seguimos, no essencial, o que propõe Alexandre Mota Pintro. Segundo este autor, apenas nas sociedades por quotas de pequena dimensão, o contrato de sociedade poderá fixar o montante de suprimentos que cada um dos sócios fiea obrigado a realizar. Se o contrato de sociedade fixar apenas um limite máximo geral de suprimentos, a sociedade aplicará o princípio da igualdade de tratamento, não podendo exigir mais a uns sócios do que a outros ${ }^{5 \%}$.

A obrigação de efectuar suprimentos poderá ainda ser constituída através de deliberação dos sócios ${ }^{5 \times}$. Neste caso, apenas ficarão vinculados à realização de suprimentos os sócios que votarem, favoravelmente, a deliberação. O contrato de suprimento só pode vincular quem o aceita c, por isso, os sócios que não votaram favoravelmente a deliberação não estão obrigados a realizar suprimentos. Aplicar-se-á aqui o princípio expresso no

"Segundo ALEXANIDRE MOTA PINTO, Do combato de Suprimento. O

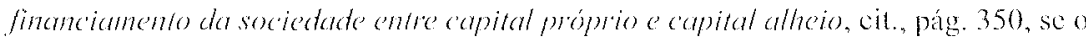
contrato de sociedade estabelecesse apenas que a sociedade poderia exigir suprimentos alos sócios, os sócios ficariam colocados numa posiçâo de grande incerteza, podendo a sociedade impor-fhes prestacoes muito superiores as entradas realizadas para a sociedade, devendo por isso lixar-se un limite máximo que, segundo o referido autor, poderia ser, por excmplo, "até ao montante correspondente "a dobro do capital social".

"VER ALEXANDRE MO'TA PINTO, Do contrato de Sumimento. Ofinanciamento da sociedade chlic capilal próprio e capilal alheio, cit., pág. 351 e RAUI. VENTURA, () contrato de sulprimonto no Código das Socredades Comeriais, cit. págs. 56 e ss.

s* Nó se exige maioria qualificada, uma vez que não há qualquer alteracão á contrato. 
art. $86 .^{\circ}$, n." 2 , no termos do qual a sociedade não pode unilateralmente criar para os sócios obrigações de quaisquer prestações ${ }^{31 "}$.

\subsection{Objecto da obrigação}

Os suprimentos têm por objecto dinheiro ou outra coisa fungível (art. 243.", n."1).

\subsection{A forma do contrato}

$O$ contrato de suprimento abrange três modalidades diferentes:

- cmpréstimo do sócio à sociedade;

- negócio sobre adiantamento de fundos;

- convenção de diferimento de créditos de sócios.

Antes da vigência do actual $\mathrm{CSC}$, o suprimento, considerado como verdadeiro mútuo, estava sujeito à forma deste último.

Actualmente, o art. 243.", n." 6, consagra a desnecessidade de qualquer formalismo, ao estabelecer que «não depende de forma especial a validade do contrato de suprimento ou de negócio sobre adiantamento de fundos pelo sócio à sociedade ou de convenção de diferimento de créditos de sócios»s. O contrato de suprimento é, portanto, um contrato consensual, podendo ser celebrado por escrito ou até verbalmente.

Situação diversa é a que ocorre quando o suprimento tem origem numa obrigação de prestação acessória. Neste caso, terão de constar do contrato de sociedade os elementos essenciais dessa obrigação e o carácter oneroso ou gratuito da prestação-suprimento (artigo 209.",

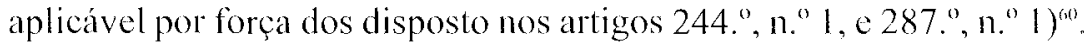

\footnotetext{
"Ver RAUL VENTURA, O comrato de stmmimento no Codigo das Sociedades Comerciais, cit., pág. 56 e ALEXANDRE MOTA PINTO, Do contrato de' Suprimento. O financiamento da sociedade cntre capilat próprio e capilal allewo, cit. págs. $353 \mathrm{e}$ ss.

A validade do contrato de sociedade depende da celebração por escritura pública (art. 7.", n. ${ }^{\circ} 1$ ) e, por isso, a maior parte dos elementos do contrato de suprimento (conteúdo, duração e modalidade) tên de ser exarados nesse documento autêntico. Ver fOÃO AVEIRO PEREIRA, O contrano de suprimento, cit., pág. 89.
} 


\subsection{Possibilidade de remuneração}

Será o contrato de suprimento um contrato oneroso ou gratuito?

A questão coloca-se no silêncio do contrato de suprimento. A lei não resolve o problema.

Entendemos que, atendendo à situação já de si bastante delicada em que se acha o credor de suprimentos, deve-se presumir o carácter oneroso do contrato de suprimento, podendo o sócio-credor exigir o reembolso do capital entregue à sociedade a título de suprimentos, acrescido dos respectivos juros.

Para fundamentar esta presunção de onerosidade, podemos chamar à colação as seguintes razões:

- do ponto de vista do sócio, uma das principais motivações é a garantia de que, das quantias empatadas em suprimentos, sempre irá obtendo algum rendimento;

- não sendo o suprimento uma entrada de capital, mas apenas um substituto desta, não $\mathrm{tem}$ de ser necessariamente e presuntivamente gratuito; muitas vezes, o suprimento representa para o sócio um investimento na própria sociedade, visando, deste modo, obter melhor rendimento do que noutra aplicação financeira"l.

Poderemos ainda recorrer às presunções de onerosidade fixadas para o mútuo civil, em caso de dúvida (arts. $1145 .{ }^{\circ}, 559 .^{\circ}$ e $806 .^{\circ}$ do C. Civil) ou para o mútuo mercantil, que é sempre retribuído (art. 395." do C. Comercial), com base no direito subsidiário (art. 2. ${ }^{\circ}$ do CSC e art. $239 .^{\circ}$ do C. Civil), sendo aplicada a taxa supletiva legal ${ }^{1,2}$.

\footnotetext{
"Ver neste sentido JOÃO AVEIRO PEREZRA, O contrato de suprimento, eit., pág. 93. Em sentido diverso, ALEXANDRE MOTA PINTO, Do contrato de Suprimento. O financiamento da sociedade entre capital proprio e capital alheio, cit., pág. 380, o qual defende que o sócio ao financiar a sociedade com suprimentos, está a proporcionar as condições para que esta venha a produzir lucros que, em parte, caberão aos sócios. Isto signilica que o sócio, ao contrário de um mutuante normal, obtém já, em certa medida, uma remuneração pela realização de suprimentos, através da fruição de lucros futuros.

Ver JOÄO AVEIRO PEREIRA, O contrato de suprimento, cit., págs. 91 e ss.
} 


\subsection{Regime de restituição}

No contrato de suprimento, a prestação a cargo do sócio deverá ser reembolsada findo o prazo que as partes hajam acordado.

Contudo, se as partes não estipularem qualquer prazo de reembolso, coloca-se a questão de saber quando poderá o titular do suprimento obter de volta o respectivo objecto.

O art. 245.', n." 1 do CSC manda aplicar o art. $777 .^{\circ}$, n. 2 do C. Civil. Assim, na falta de estipulação de prazo, cabe ao tribunal fixar o respectivo prazo de reembolso, através de um processo de jurisdição voluntária e segundo critérios de conveniência e oportunidade.

Há, todavia, certas limitações ao direito de recmbolso, estabelecidas em nome da proteç̧ão dos credores externos da sociedade.

En caso de falência da sociedade, a posição dos sócios credores por suprimentos é objecto de limitações, vedando-lhes a lei a possibilidade de por esses créditos requererem a falência da sociedade, ainda que possam participar dos efeitos de uma concordata (art. 245.", n. $\left.{ }^{0} 2\right)^{n 3}$.

Refira-se, igualmente, que, em caso de falência, se tiverem sido reembolsados créditos por suprimentos durante o ano anterior à declaração de falência da sociedade, esse reembolso é resolúvel (art. $\left.245^{\circ}, \mathrm{n}^{\circ} .5\right)^{(4.4}$.

Também, em caso de dissolução da sociedade, a lei condiciona a restituição dos suprimentos. $O$ art. $245 .^{\circ}$, n. 3 estabelece que, em qualquer caso de dissolução da sociedade, os suprimentos só podem

\footnotetext{
n.s. Fsta proibição de os credores por suprimentos requererem a falência não é uma proibição absoluta, uma vez que cles poderão sempre requerê-lo se forem titulares de créditos sobre a mesma sociedade, não por suprimentos, mas a outro titulo. Ver, neste sentido, JOÃO AVEIRO PEREIRA, O contrato de suprimento, cil., pág. 98.

(n Segundo RAUL VENTURA, O contrato de suprimento no Código das Sociedades Comerciais, cil., pág. 67, este regime especial justifica-se pela "funçăo dos suprimentos relativamente ao capital social; o sócio faz um suprimento para substituir uma entrada de capital c apesar disso mantém um crédito contra a sociedade; não deve, todavia, levar a sua qualidade de credor ao ponto de, invocando-a com esquecimento da especialidade do seu crédilo, requerer a faléncia da sociedade que pelo suprimento pretendia financiar".
} 
ser reembolsados depois de inteiramente pagas as dívidas da sociedade para com os outros credores e não podem ser compensados créditos da sociedade por créditos por suprimentos ${ }^{1,5}$.

Outra disposição que visa a proteção de terceiros é a proibição de que se convencionem garantias reais prestadas pela sociedade em benelïcio dos credores por suprimentos. Tais garantias, a existirem, scrão nulas (art. 245.", n." 6) . A garantia real cria uma preferência, relativamente a certos bens, em proveito dos respectivos eredores. Se tais garantias forem lícitas, os sócios delas beneficiários gozariam de preferência relativamente aos credores estranhos, desaparecendo praticamente a prioridade estabelecida a favor destes últimos no art. $245^{\circ}$, n." 3.

Em conclusão, poderemos alirmar que a lei condiciona fortemente a restituição dos suprimentos. Assim, na ausência de prazo de recmbolso, cabe ao tribunal a fixação do mesmo e em caso de falência os suprimentos só podem ser reembolsados depois de pagos os outros credores (art. 245.").

\subsection{Sanção do incumprimento}

O incumprimento da obrigação de electuar suprimentos não é sancionado, tal como acontece com a obrigação de efectuar prestações suplementares com a perda, total ou parcial, da quota e eventualmente com al exclusão da sociedade (arts. $212 . "$, n." 1 , 204." e 205."). Todavia, nada impede, pelo menos no caso das sociedades por quotas, que os estatulos prevejam que tal incumprimento seja fundamento de exclusão ou de amortização da quota (arts. 209.", n." 4, 287.", n." 4, $241 . "$ n." 1, 232." n." I c 233. ., n." 1 ).

\footnotetext{
"A compensaçăo destruiria a prioridade dos créditos de terceiros.

"Por exemplo, uma sociedade nâo pode constituir um penhor de todos os seus bens móveis a lavor dos sócios tifulares de suprimentos, passando esses bens para a posso desses sócios. Vor neste sentido, JOX̃O AVEIRO PEREIRA, O contrato de stujrimento, cit, pág. 106.
} 


\subsection{Tratamento contabilístico}

A face do Plano Oficial de Contabilidade, os suprimentos são um elemento do passivo (reconduzível à conta 25 , aliás em obediência a uma nota à conta 53). Os suprimentos não são tratados como capital próprio, mas como capital alheio, devendo ser inscritos como passivo no balanço, uma vez que se trata de dívidas sociais.

\section{Conclusão}

Os suprimentos săo um meio contratual de financiamento da sociedade pelos sócios, constituindo uma resposta importante nas situações de subcapitalização nominal das sociedades. Assim, os sócios en vez de realizarem um aumento do capital social, reforçando os capitais próprios, procedem a empréstimos à sociedade. Este meio de financiamento permite aos sócios obter una remuneração do investimento que realizaram, não onerando a sua responsabilidade pelas dívidas sociais que se mantém limitada ao montante do capital social.

Refira-se finalmente, que estas práticas de os sócios porem à disposição da sociedade outros fundos, para além das entradas, são tão antigas quanto as próprias sociedades comerciais. Já o nosso Código de Ferreira Borges (1833) afirmava num dos scus preceitos (conservando a grafía da época):

«656. Todo o socio tem direito a pedir os juros de desembolso, que faça de dinheiro seu para vantagem commum social. (...)». 


\section{Bibliografia}

- ABREU, Jorge Coutinho de, Da empresarialidade, Almedina, 1999

- CORRLIA, Miguel Pupo, Direito Comercial, 8." Edição, Ediforum, Lisboa, 2003.

- Domingues, Paulo Tarso, Do capital social. Noção, Principios e Funções, Coimbra Editora, 1998.

- DOMingues, Paulo Tarso, Garantias da Consisténcia do Património Social, in: Problemas do Direito das Sociedades, Almedina, 2003.

- FURTADO, Jorge Pinto, Curso de Direito das Sociedales, 4. Edição, Coimbra, Almedina, 2001.

- PEREIRA, João Avciro, O contrato de suprimento, 2." Edição, Coimbra Editora, 2001 .

- PINTO, Alexandre Mota, Do contrato de Staprimento, O financiamento da sociedate entre capital proprio e capital alheio, Almedina, 2002.

- VASCONCELOS, Pedro Pais de Vasconcelos, As obrigaçós no financiamento da empresa, in Problemas do Direito das Sociedades, Almedina, 2003.

- VENTURA, Raul, O contrato de suprimento no Código dess Sociedades Comerciais, Revista (O Dircito, Ano 121., Janeiro-Matço, 1989. 